\title{
The Identification of Multiple Intelligence in Relation to English Achievement of the Sixth Graders of SD Negeri 32 Palembang
}

\author{
Kurnia Saputri \\ Universitas Muhammadiyah Palembang \\ kurniasaputri93@gmail.com
}

\begin{abstract}
The Identification of Multiple Intelligence in relation to English Achievement of the sixth graders of SD N 32 Palembang. Based on the data analysis, there were five major findings: First, linguistic, logical, spatial, musical, and interpersonal intelligences were types of intelligence of the sixth graders. Second, most of the students dominantly have interpersonal intelligence. Third, based on the calculation of $\mathrm{z}$ scores (standard scores), Logical-Ma thematical intelligence was the type of intelligence that had better English achievement because this type had the positive scores higher than the negative scores. Fourth, the variance of population was homogeneous. Fifth, the mean value of population was homogeneous and correlated each other.
\end{abstract}

Key words: English achievement and multiple intelligences.

\section{INTRODUCTION}

Learning achievement may depend on several factors that can be classified into internal and external factors. According to Sumadi Suryabrata as cited in Himayana (2006:1) learning achievement is influenced by external and internal factors that form association of several sub factors. The external factors consist of environmental factors such as natural and social environment, and instrumental factors such as curriculum, facilities and teachers. The internal factors consist of physiological factors such as body condition and 
five senses, and psychological factors such as talent, interest, intelligence, motivation and cognitive style.

According to Sayderman and Rothman as cited in Robent E. Slavin (1997-131), intelligence is a general aptitude for learning, often measured by the ability to deal with abstraction and to solve problems. The concept of intelligence has been discussed since before the time of the Ancient Greeks, but the scientific study of the topic just began with the work of Alfred Binet, who devised the first measure of intelligence in 1904. The French asked Binet to find a way to identify children who needed special help in their schooling. His measure assessed a broad range of skills and performances but produced a single score, called Intelligence Quotient (IQ).

Then, it becomes famous that people use Intelligence Quotient (10) to measure someone's intelligence. People judge that someone who has a high score on his IQ test is a special and will be more successful than the one who gets lower. But then some researchers in the field of intelligence have long argued that people have a variety of different intelligences. A person may be good at learning language and terrible of learning music or vice vena. Many people are terrific at calculate could not write a good essay or paint a good picture. Some people can walk into a room full of strangers and immediately figure out the relationships and feelings among them; other might never learn the skill. A single number (a score on a 10 est.) cannot adequately represent the complex and diverse capabilities of a human being (Synderman and Rothman in Robert E. Slavin, 1997: 1311.

Intelligence is a mixture of several abilities. Dr. Howard Gardner, Professor of Education st Harvard University developed the theory of Multiple Intelligences in 1983. It suggests that the traditional notion of intelligence, based on $1 \mathrm{Q}$ testing is very limited. Instcad, Gardner proposes eight different intelligences to account for a broader range of human potential. These Intelligences are; Linguistic intelligence ("word smart Logical - mathematical intelligence ("number / reasoning sman"). Spatial intelligence 
("picture smart), Bodily-Kinesthetic intelligence ("body smart), Musical intelligence music smart). Interpersonal intelligence (peopliesmarnt Intrapersonal intelligence (nature smart).

The former studies done by Surip (1994:42) and Kirana (2005:21) dealt with English achievement and reading achievement and Shearer (2006:26) dealt with Math skill. Surip (1994: 42) found that the levels of the students' intelligence influence the students' English achievement. The students with high level of intelligence tend to be better in English achievement than those with low level of intelligence. Shearer (2006:26) found that High Math skill is most directly related to the logical - math and intrapersonal intelligences and to a lesser degree of the linguistic intelligence. Those studies indicate that the intelligence is one of the internal factors which may influence the students' achievement. But, the studies about multiple intelligences themselves are still seldom done. Moreover, the research about multiple intelligence conducted at elementary school is never done by the previous researchers. As we know, parents should know earlier their children' types of intelligence beginning from elementary school in order to make it easier for them to develop their children' future later.

\section{THEORITICAL FRAMEWORK}

\section{Intelligence Related to Achievement}

Learning is the combination of how we absorb, manage, and process the information. It is the perceptual and cognitive skills and strategies the learner uses in gathering, interpreting and storing information. According to Deporter and Heremacki (2003:110) cited in Heri (2003) that there are two main categories concerned about the way people learn; (1) how people perceive information with perceptual modality learning style and (2) how people organize and process those information by using brain dominance.

Achievement refers to something achieved, something done successfully with effort and skill (Hornby, 1974:48). In our daily life, 
achievement can be result. Gardner (1999) has identified eight different types of intelligences that each individual has the capacity to posses. The idea of multiple intelligences is important because it allows for educators to identify different strengths and weaknesses in students and also contradicts the idea that intelligence can be measured through IQ only, and it also related to the two main categories, which must be concerned about the way people learn.

\section{The Concept of Intelligence}

According to Oxford Dictionary, intelligence is the ability of living creatures to process information. Papalia and Olds (1988:132) state that the countless concepts of what intelligence is range from a genetically endowed, inborn, general capacity to develop number of intellectual abilities to the ability to do a variety of specific things and to engage in rational, productive behavior and to "whatever intelligence tests Santrock (1991 251) says that intelligence is one or more abilities a person has, the ability to reason, solve problem, think abstractly rather than concretely to the new situation and generalize the new solution of other problems. Furthermore, Wechster (1975) in Feldman (1989.213) asserts intelligence as the apucity to understand world, think rationally, and use resources effectively when focus the challenges. In addition, Piaget as cited in Bootzin (1986:370) says that intelligence does not by any means appear at once derived from those which have preceded it. Intelligence presents, on the contrary, a remarkable continuity with the acgaired or even inborn process in which it depends and at making the use of time. Sternberg as cited in Santrock, John W. \& Laster M. Sdorow (2000:298) defines intelligence as the mental capacity to automatist information processing and to emit contextually appropriate behavior in response to novelty. He proposes a Triarchic theory of intelligence with these aspects: componential intelligence, experiential intelligence, and contextual intelligence. While Gardner as cited in Gregory (2004:153) define intelligence as the ability or skill to solve problems or to fashion products that are valued within one or more cultural setting. He proposes a theory of Multiple Intelligences based loosely upon the 
study of brain behavior relationships. He argues for the existence of several relatively independent intelligences, including linguistic, musical, logical-mathematical, spatial, bodily-kinesthetic, personal, intrapersonal, and naturalist. In spite of this diversity of view points, two themes recur again and again in expert definitions of Intelligence. Broadly speaking, the experts tent to agree that intelligence is (1) the capacity to learn from experience, and (2) the capacity to adapt to one's environment.

\section{The Concept of Multiple Intelligences}

Multiple Intelligence Theory was developed by Howard Gardner. He defined multiple intelligence as the ability to create an effective product or offer a service that is valued in a culture; a set of skills that make it possible for a person to solve problems in life; the potential for finding or creating solutions for problems, which involves gathering new knowledge. There are 8 types of Multiple Intelligence that would be explained below.

The idea of multiple intelligence comes out of psychology. It is a theory that was developed to document the fact that human beings have very different kinds of intellectual strengths and that these strengths are very important in how kids learn and how people represent things in their minds and then how people use them in order to show that it is that they have understood. If we all had exactly the same kind of mind and there was only kind of intelligence, then we could teach everybody the same thing in the same way and asses them in the same way that would be fair. But once we realize that people have very kinds of minds, different kinds of strengths, some people are good in thinking spatially, some people are good in thinking language, other people are very logical, other people need to do hands on, they need to actually explore actively and to try things out. Once we realize that, then education which treats everybody the same way is actually the most unfair education.

Harvard Professor Howard Gardner as cited in Tan Oon Seng, et al (2003:121) has defined eight different types of intelligences that 
each individual has the capacity to posses. The idea of multiple intelligences is important because it allows for educators to identify differing strengths and weaknesses in students and also contradicts the idea that intelligence can be measured through IQ only.

\section{The Principles of Multiple Intelligences}

There are six principles of Multiple Intelligences 2.4 (http:/leader.louisville.eduedt/kemp/edtl501/spring03/learn/mi.p pt), they are:

1. It is important to teach subject matter through a variety of activities and projects;

2. Assessments should be integrated into learning. And students need to play an active role in their assessment. When a student helps determine and clarify the goals of classroom activities, his or her academic success and confidence increases. 3. Offer students a number of choices for 'showing what they know 4. Intelligence is not singular: intelligences are multiple 5. Multiple intelligences can be identified and described 6 . The use of one of the intelligences can be used to enhance intelligence.

\section{Types of Intelligence}

According to Gardner as cited in Rose (1997:59), there are at least eight different types of intelligence. Depending on the background and age, some intelligences are more developed than others. He suggests most of us are strong at least in three types.

\section{Visual/Spatial Intelligence}

The ability to perceive the visual. These learners tend to think about pictures and need to create vivid mental images to retain information. They enjoy looking at maps, charts, pictures, videos, and movies. Their skills include: puzzle building, reading, writing understanding charts and graphs, a good sense of direction, sketching painting, creating visual metaphors and analogies 
(perhaps through the visual arts), manipulating images, constructing, fixing, designing practical object, interpreting visual images. Possible career interests: navigators, sculptors, visual artists, inventors, architects, interior designers, mechanics, and engineers.

\section{Verbal/Linguistic Intelligence}

The ability to use words and language. These learners have highly developed auditory skills and are generally elegant speakers. They think in words rather than pictures. Their skills include: listening, speaking, writing, telling a story, explaining, teaching, using humor, understanding the syntax and meaning of words, remembering information, convincing someone of their point of view, analyzing language usage. Possible career interests: poet, journalist, writer, teacher, lawyer, politician.

\section{Logical/Mathematical Intelligence}

The ability to use reason, logic and numbers. These learners think conceptually in logical and numerical patterns making connections between pieces of information. Always curious about the world around them, these learners ask lots of questions and like to do experiments. Their skills include: problem solving, classifying and categorizing information, working with abstract concepts to figure out the relationship of each to the other, handling long chains of reason to make local progression, doing controlled experiments, questioning and wondering about natural events, performing complex mathematical calculations, working with geometric shapes. Possible career paths: scientist, engineers, computer programmers, researchers, accountants, mathematician.

\section{Bodily/Kinesthetic Intelligence}

The ability to control body movements and handle objects skillfully. These learners express themselves through movement. They have a good sense of balance and eye-hand co-ordination (e,g. ball play, balancing beams). Through intercting with the space around them, they are able to remember and process information. 
Their skills include: dancing, physical co-ordination, sports, hands on experimentation, using body language, crafts, acting, miming, using their hands to create or build, and expressing emotions through the body. Possible career paths: athletes, physical education teacher, dancers, actors, firefighters, and artisans.

\section{Musical/Rhythmic Intelligence}

The ability to produce and appreciate music. These musically inclined learners think in sounds, rhythms and patterns. They immediately respond to music either appreciating or criticizing what they hear. Many of these learners are extremely sensitive to environmental sounds (e.g. crickets, bells, dropping taps). Their skills include: singing, whistling, playing musical instruments, recognizing tonal patterns, composing music, remembering, melodies, understanding the structure and rhythm of music. Possible career paths: musician, disc jockey, singer and composer.

\section{Interpersonal Intelligence}

The ability to relate and understand others. These learners try to see things from other people's point of view in order to understand how they think and feel. They often have an uncanny ability to sense feelings, intentions and motivations. They are great organizers, although they sometimes resort to manipulate. Generally they try to maintain peace in group settings and encourage cooperation. They use both verbal (e.g. speaking) and non-verbal language (e.g. eye contact, body language) to open communication channels with others. Their skills include: seeing things from other perspective (dual-perspective, listening, using empathy, understanding other people's mood and feelings, counseling, cooperating with groups, noticing people's moods, motivations and intentions, communicating both verbally and non-verbally, building trust, peaceful conflict resolution, establishing positive relations with other people. Possible career paths: counselor, salesperson, politician, business person.

\section{Naturalist Intelligence}


The ability to understand different species, recognized patterns in nature, classify natural objects. These learners try to discriminate among living things (plants, animals) as well as sensitivity to other features of the natural world. Their skills include: recognizing their own strengths and weaknesses, reflecting and analyzing themselves, awareness of their inner feelings, desires and dreams, evaluating their thinking patterns, reasoning with themselves, understanding their role in relationship to others. Possible career paths: researchers, theorists, philosophers.

\section{Cognitive Development Theory}

Unlike behaviorism, the cognitive theory focuses on what is going on inside the student's mind. Learning is not just a change in behavior; it is a change in the way a student thinks, understands, or feels. There are two branches of cognitive theory. Two of the major theories may broadly be classified as the information processing model and the social interaction model. The first says that the student's brain has internal structures which select and process incoming material, store and retrieve it, use it to produce behavior, and receive and process feedback on the results. This involves a number of cognitive processes, including executive functions of recognizing expectancies, planning and monitoring performance, encoding and chunking information, and producing internal and external responses.

The second says the social interaction theories stress that learning and subsequent changes in behavior take place as a result of interaction between the student and the environment. Behavior is modeled either by people or symbolically. Thus, the social environment to which the student is exposed demonstrates or models behaviors, and the student cognitively processes the observed behaviors and consequences. The cognitive processes include attention, retention, motor responses, and motivation. Techniques for learning include direct modeling and verbal instruction. Behavior, personal factors, and environmental events all 
work together to produce learning. Cognitive development theories are clearly explained in Piaget Theory and Vygotsky Theory.

\section{Piaget Theory}

According Piaget, first the child as active learner. Piaget's concern was with how young children function in the world that surrounds them, and how this influences their mental development. The child is seen as continually interacting with the world around her/him, solving problems that are presented by the environment. It is through taking action to solve problems that learning occurs. For example, a very young child might encounter the problem of how to get food from her bowl into her mouth. In solving the problem, with a spoon or with fingers, the child learns the music control and direction-finding needed to feed herself. The knowledge that results from such action is not imitated or in-bon, but is actively constructed by the child.

Piaget differentiates two says in which development can take place as a result of activity : assimilation and accommodation. Assimilation happens when action takes place without any change to the child; accommodation involves the child adjusting to features of the environment in some way. Returning to the example of feeding, let's imagine what might happen when a child, who has learnt to use a spoon, is presented with a fork to eat with. She may first use the fork in just the same way as the spoon was used; this is assimilation of the new tool to existing skills and knowledge. When the child realizes that the prongs of the fork offer new eating opportunitiesspiking food rather than just 'spooning' it - accommodation occurs; the child's actions and knowledge adapt to the new possibility and something new is created.

The second, the child as sense maker. We can take from Piaget the very important idea of the child as an active learner and thinker, constructing his or her own knowledge from working with objects or ideas. Donaldson's emphasizes that the child actively tries to make sense of the world ....asks questions,.....wants to know....also from a 
very early stage the child has purpose and intentions; he wants to do. (Donaldson 1978:86).

Piaget divides the child's path of development into four stages which began with birth and culminated in the teen years. These stages are:

1. Sensorimotor stage (birth - 2 years old) -- Child interacts with environment through physical actions (sucking, pushing, grabbing, shaking, etc.) These interactions build the child's cognitive structures about the world and how it functions or responds. Object permanence is discovered (things still exist while out of view).

2. Preoperational stage (ages 2-7) -- Child is not yet able to form abstract conceptions, must have hands-on experiences and visual representations in order to form basic conclusions. Typically, experiences and visual representations in order to form basic conclusions. Typically, experiences and visual representations in order to form basic conclusions. Typically, experiences must occur repeatedly before the child grasps the cause and effect connection.

3. Concrete operations (ages 7-11) -- Child is developing considerable knowledge base from physical experiences. Child begins to draw on this knowledge base to make more sophisticated explanations and predictions. Begins to do some abstract problem solving such as mental math, etc. still understands best when educational material refers to real life situations.

4. Formal operations (beginning at ages 11-15) -- Child's knowledge base and cognitive structures are much more similar to those of an adult. Ability for abstract thought increases markedly.

\section{Vygotsky Theory}


The child as social. Vygotsky views of development differ from Piaget's in the importance he gives to language and to other people in the child world. Although Vygotsky theory is currently most noted for his central focus on the social, and modern developments are often labeled 'sociocultural theory', he did not neglect the individual or individual cognitive development.

Underlying Vygotsky theory is the central observation that development and learning take place in a social context, i.e. in a world full of other people, who interact with the child from birth onwards. Whereas for Piaget the child is an active learner alone in a world of objects, for Vygotsky the child is an active learner in a world full of other people. Those people play important roles in helping children to learn, bringing objects and ideas to their attention, talking while playing and about playing, reading stories, asking questions, in a whole range of ways, adults mediate the world for children and make it accessible of human intelligence. With the help of adults, children can do and understand much more than they can on their own.

The word is a recognizable linguistic unit for children in their first language and so they will notice words in the language. Often too we teach children in their first language and so they will notice words in the new language. Often too we teach children words in the new language by showing them objects that they can see and touch, and that have single word labels in the first language. From their earliest lessons, children are encouraged to think of the new language as a set of words, although of course this may not be the only way they think of it. Vygotsky used the idea of the ZPD (Zone of Proximal Development) to give a new meaning to intelligence. Rather than measuring intelligence by what a child can do alone, Vygotsky suggested that intelligence was better measured by what a child can do with skilled help.

\section{Children Learning Language}

\section{Bruner's Theory}

For Bruner, language is the most important tool for cognitive growth, and he has investigated how adults use language to mediate the world for children and help them to solve problems (Bruner 1983, 
1990). Talk that supports a child in carrying out an activity, as a kind of verbal version of the fine-tuned help given in the baby feeding example above has been labeled scaffolding (Wood, Bruner and Ross 1976). In experiments with American mothers and children, parents who scaffolded tasks effectively for children did the following:

- They made the children interested in the task

- They simplified the task, often by breaking it down into smaller steps

- They kept the child on track towards completing the task by reminding the child of what the goal was

- They pointed out what was important to do or showed the child other ways of doing parts of the tasks

- They controlled the child's frustration during the task

- They demonstrated an idealized version of the task

Moreover, good scaffolding was tuned to the needs of the chid and adjusted as the child became more competent. Scaffolding has been transferred to the classroom and teacher-pupil talk.

\section{Concepts of Young Learners}

Scott and Ytreberg (1990:1-4) divide young learners into two main groups the five to seven year olds and the eight to ten year olds. The characteristics are:

Five to seven year olds

General Characteristics:

- They can talk about what they are doing.

- They can tell you about what they have done or heard.

- They can plan activities.

- They can argue for something and tell you why they think what they think.

- They can use logical reasoning.

- They can use their vivid imagination. 
- They can use a wide range of intonation patterns in their mother tongue.

- They can understand direct human interaction.

Language Development:

- They know that the world is governed by rules. They may not always understand the rules, but they know that they are there to be obeyed, and the rules help to nurture a feeling of security.

- They understand situations more quickly than they understand the language used.

- They used language skills long before they are aware of them.

- Their own understanding comes through hands and eyes and ears. The physical world is dominant at all times.

- They are very logical-what you say first happens first. 'Before you turn off the light, put your book way' can mean 1 . Turn of the light 2. Put your book away.

- They have a very short attention and concentration span.

- Young children sometimes halve in knowing what fact is and what fiction is. The dividing line between the real world and the imaginary world is not clear.

- The adult world and the child's world are not the same. Children do not always understand what adults are talking about. Adults do not always understand what children are talking about. The difference is that adults usually find out by asking question, but children do not always ask. They either pretend to understand, or they understand in their own terms and do what they think you want them to do.

- Young children cannot decide for themselves what to learn.

- Young children love to play, and learn best when they are enjoying themselves. But they also take themselves seriously and like to think that what they are doing is 'real' work.

- Young children are enthuastic and positive about learning. 
General Characteristic:

- Their basic concepts are formed. They have very decided views of the world.

- They can tell the different between fact and opinion.

- They ask questions all the time.

- They rely on the spoken word as well as the physical word to convey and understand meaning.

- They are able to make some decisions about their own learning.

- They have definite views about what they like and do not like doing.

- They have a developed sense of fairness about what happens in the classroom and begin to question the teacher's decisions.

- They are able to work with others and learn from others.

Language Development:

- They have a language with all the basic elements in place. They can understand abstracts and symbols (beginning with words). Also, they can generalize and systemize.

Similarly, De Nagy (2005) states that young learners refer to the children from the ages of four tp twelve. The classification and the characteristics of them are shown as follow:

Four to six year olds

Experience of Formal Tuition:

- No school readiness skill.

- No experience of formal tuition.

Knowledge of the world:

- Limited-depends on home background. Ability to read and write:

- Not able to or beginning to learn.

Seven to none year olds

Experience of Formal Tuition: 
- Have had 1-2 years of primary school.

- Learning to read and write, etc.

- Some school readiness.

Knowledge of the world:

- Some but still mainly concerned to own reality. Ability to read and write:

- Confident but for some still very much in the learning process.

Ten to twelve year olds

Experience or formal tuition:

- Complete or completing primary school.

- Three to five years of formal education.

- Because of above, expectation with regard to teacher/learning, etc.

- Awareness of how to behave.

Knowledge of the world:

- More extensive-influenced by educational process-outside factors, etc.

- Proficient.

Characteristics of Young Learners Based on their Types of Intelligences

\section{Verbal/Linguistic Intelligence}

- Asks lots of question

- Enjoys talking

- Has a good vocabulary

- Can pick up a new language easily

- Enjoys playing with words (e.g. word games, puns, rhymes)

- Enjoys reading

- Likes to write

- Understanding function of language 
- Is good at memorizing names, places, dates and trivial

\section{Logical/Mathematical Intelligence}

- Enjoys solving puzzles

- Playas with number (counting)

- Wants to know how thing work

- Likes to collect and classify things

- Does well at math, reasoning, logic, and problem solving

\section{Visual/Spatial Intelligence}

- Likes to draw

- Likes to take things a part

- Likes to build thing

- Enjoy puzzles

- Likes to doodle

- Has a good sense of parts to the whole

- Remembers places by descriptions or images

- Can interpret maps

- Is a good imagining thing, sensing, changes, mazes/puzzles, reading maps and charts.

\section{Bodily/Kinesthetic Intelligence}

- Has a good sense of balance

- Is good graceful in movement

- "reads" body language

- Can communicate ideas through gesture

- Is good physical activities (e.g. sport, dance, acting) and crafts

\section{Musical/Rhythmic Intelligence}

- Is sensitive to sound patterns

- Hums tunes

- Taps or sways in rhythm

- Has a good sense of pitch

- Moves rhythmically

- Remembers tunes and sound patterns

- Seeks and enjoys musical experiences 
- Plays with sound

- Is good at remembering melodies

6. Interpersonal Intelligence

- Demonstrates empathy toward others

- Is admired by peers

- Relates well to peers and adults like

- Works cooperatively with others

- Is sensitive to the feelings of others

- Is good at understanding people

\section{7. intrapersonal Intelligence}

- Can express strong like or dislike of particular activities

- Can communicate feelings

- Is confident of own abilities

- Likes being original

- Is good at pursuing own interests and goals

\section{Naturalistic Intelligence}

- Understand different species

- Recognize patterns in nature

- Classify natural objects

- Discriminate among living things (plants, animals) as well as sensitivity to others features of the natural world. http://www.cambridgeesol.org/exams/young-learners/yle.html.

\section{RESEARCH METHODOLOGY}

This study is conducted by applying descriptive method. Descriptive research involves the collection of data in order to test hypotheses or to answer questions concerning the current status of the subjects of the study (Wasson, 2002 as cited in Nurdianita, 2007:31). Best and Khan (1935:105) state: A descriptive method study describes and interprets what it is. It is concerned with conditions or relationships that exist, opinion that are held, processes that are going on, effects that are evident, or trends that are developing. It is primarily concerned with the presents, although 
it often considers past events and influences as they are related to current condition. While Popham and Sirotnik (1967:4) state that descriptive method is used to describe the data and summarize sets of numerical data such as test scores, ages and years of education.

There are two kinds of variables in this study, the independent variable and the dependent variable. Independent variables are those the researcher chooses to study in order to asses their possible affect(s) on one or more other variables. Dependent variables are those which are affected by the independent variables (Fraenkel and Wallen, 1991: 25). The independent variable of this study is students" multiple intelligences, while the dependent variable is English achievement of the sixth graders of SD Negeri 32 Palembang.

The title of this research is "The Identification of Multiple Intelligences in relation to English Achievement of the Sixth Graders of SD Negeri 32 Palembang To avoid misinterpretation, some terms will be explained. Multiple Intelligences refers to the types of intelligence. They are linguistic intelligence, logical-mathematical intelligence, spatial intelligence, bodily-kinesthetic intelligence, musical intelligence, interpersonal intelligence, intrapersonal intelligence, and naturalist intelligence (Rose, 1999:77). Identification is derived from the word "identify" means to find out something. So, identification is the act of identifying something. English Achievement refers to the result of an English lesson taken from the students' semester examination result (summative test).

A population is a group of elements or cases whether individuals, objects or events that confirm to specific criteria and to which we intend to generalize the result of the research (McMillan, 1992:78). The population of this study is the sixth-grade students of SD N 32 Palembang in academic year 2007/2008 with a total number of 73 students. Table 1 shows the population of the study.

Actually, taking the samples depends on how many subjects included in the population. Since the total number of subjects in 
population of this study were less than 100 students, the writer decide to take all subjects in population as samples. This was based on what Arikunto (1996: 45) states that if the subjects are less than 100 , it is better to take all subjects in population. The sampling method is commonly called "Non probability samples" According to Best (1993:18), non probability samples use whatever subjects are available rather than following a specific subject selection process. Finally, it can be concluded that the sample was the same as the population. The sample was 73 sixth graders of SD Negeri 32 Palembang which consisted of two classes: IV A and IV B.

The data of the study would be classified into two groups, (1) the data gained from the questionnaire and (2) documentation.

\section{Questionnaire}

Arikunto (1996:128) states that a questionnaire is the amount of written questions, which are used to obtain information from respondents' deals with the report about themselves, and things that they know.

To know the students' type of intelligence, the writer used ready-made questionnaire taken from Rose, Collin, and Malcom J. Nicholl (1997). The questionnaire was distributed to the sixth grade students and is translated into Indonesian. The questionnaire consists of 8 types of multiple intelligences. Each type is presented by 10 questions. Question number 1, 2, 11, 12, 21, 31, 41, 51, 61, and 71 are linguistic intelligence; $3,13,22,23,32,33,42,52,62$, and 72 are logical-mathematical intelligence; 4, 14, 24, 34, 43, 44, 53, 54, 63, and 73 are spatial intelligence; $5,15,25,35,45,55,64,65,74$, and 75 are bodily-kinesthetic intelligence; $6,7,16,17,26,36,46,56,66$, and 76 are musical intelligence; $8,18,27,28,38,37,47,57,67$, and 77 are interpersonal intelligences; $9,19,29,39,48,49,58,59,68$, and 78 are intrapersonal intelligence; $10,20,30,40,50,60,69,70,79$, and 80 are naturalist intelligence and the writer would explain to the students soon if they have problems with the questions. Each item of question is provided with two options (yes or no). the students 
simply chose the options by giving the check $(\sqrt{ })$ on the answer sheet at the appropriate column.

\section{Documentation}

The writer would use the current results of English achievement test of the Sixth Graders of SDN 32 Palembang in the academic year of $2007 / 2008$. The score would be collected by the writer. These grades were classified into these categories:

Table 1.

The Category of Students' Grade

\begin{tabular}{|l|l|l|}
\hline No & $\begin{array}{l}\text { Score } \\
\text { Interval }\end{array}$ & Category \\
\hline 1 & $86-100$ & Very Good \\
\hline 2 & $71-85$ & Good \\
\hline 3 & $56-70$ & Average \\
\hline 4 & $41-55$ & Poor \\
\hline 5 & $1-40$ & Very Poor \\
\hline
\end{tabular}

Source of score interval: SDN 32 Palembang 20017/2008

Since this study is a quantitative study, statistics would be used. The statistical analysis applied to verify the problem of the study is the Anova test and Levena test (Test of Homogeneity of Variances). The calculation was done by using SPSS version 12.00 . This analysis would be used in order to find out: (1) which types of multiple intelligences appear of the Sixth Graders of SDN 32 
Palembang, (2) after that the writer put the types of multiple intelligences based on their own groups, for example type of intrapersonal intelligence would be put in intrapersonal intelligence group, (3) then, the writer would calculate the percentage of each multiple intelligence type with the average score of students' English achievement of each multiple type. Finally, the writer would find out which dominant types of multiple intelligences have better English achievement.

\section{FINDINGS AND DISCUSSION}

From each type of multiple intelligence, it was found that the students were dominant in interpersonal intelligence because from 68 students as the sample, there were 18 students / $24.66 \%$ ( the highest total of students ) belong to this type of intelligence. The distribution of students' English achievement score showed that none of the students in very good category , 10 students ( $13.69 \%$ ) were in good category, 22 students ( $30.14 \%$ ) were in average category , 25 students ( $34.25 \%$ ) were in poor category, and 13 students ( $21.92 \%$ ) were in very poor category. The writer also found that from 8 types of multiple intelligence which she distributed through ready-made questionnaire to the sixth graders of SD Negeri 32 Palembang, there were only 5 types of intelligent most appear of them (many students were in these 5 types), they were linguistic, logical-mathematical, spatial, musical and interpersonal intelligences.

The writer has read one of papers presented at RELO (Regional English Language Officer) seminar, entitled "Teaching Using Multiple Intelligences Psychological Perspectives" by Dr. Khoiruddin Bashori (the Rector of University of Muhammadiyah Yogyakarta". He explained that our education doesn't develop intelligence very specifically yet but most of the parents usually use the students' scores in the report book as the reflection of children's intelligence. The children who get high rankings, good in mathematics and memorizing hard are always categorized as smart 
students. Our education seems to focus on the existing potential use of Linguistic and Logical-mathematical intelligence. That is why most of our students only focus on that intelligence.

One thing we must remember that students' type of intelligence was not the only factor influencing the students' English achievement, some other factors could be involved beside students' intelligence. According to Sumadi Suryabrata as cited in Surip (1995:1).learning achievement is influenced by external and internal factors that form association of several sub factors. The external factors consist of environmental factors such as natural and social environment, and instrumental factors such as curriculum, facilities and teachers. The internal factors consist of physiological factors such as body condition and five senses, and psychological factors such as talent, interest, intelligence, motivation, and cognitive style. Such result could happen because of the weaknesses on instruments, the writer, and the students themselves (the honesty on answering the questionnaire, wrong interpretations of the questions asked, etc). All of the factors should be taken into account.

\section{Type of Intelligence that has better English Achievement}

From the result of the multiple intelligence questionnaires and the students English achievement, it was found that from 73 students, there were 11 ( $15.07 \%$ ) students who are dominant in Logical-Mathematical intelligence. 2 of them were had very poor score, 3 of them got poor score, 3 of them got average score, 3 of them got good score while none of them got very good score. To decide which type of multiple intelligence had better English achievement, the writer used z score as a standard scores that useful of describing a raw score's position in a distribution expressing the score's distance above or below the mean score. After calculating the $\mathrm{z}$ score, we would get the positive scores and the negative scores. Type of multiple intelligence which had better English achievement was depend on the total of positive scores must be higher than the negative scores in each types of intelligence. The formula of $z$ score 
itself is as follows: Where: Standard Score (Z score) x English Score Z Mean Score per each types of multiple intelligence o Standard Deviation per each types of multiple intelligence.

After the calculation of the $\mathrm{z}$ scores in each type of intelligence, it was found that Logical-Mathematical intelligence was the type of intelligence that had positive scores higher than negative scores while others have the same scores between negative and positive scores or even the negative scores higher than positive scores (appendix E).It can be concluded that the students who had Logical-Mathematical intelligence had better English Achievement.

\section{CONCLUSION}

From all of the descriptions and explanations discussed in the previous chapter. This chapter draws five conclusions and four suggestions. Conclusions based on the result of the study and the interpretation, five conclusions can be drawn. First, linguistic, logical, spatial, musical, and interpersonal intelligences were types of intelligence most appear to the sixth graders. Second, most of the students dominantly have interpersonal intelligence. Third, It can be concluded that the students who had Logical-Mathematical intelligence had better English achievement because based on the calculation of z scores, only Logical-Mathematical intelligence which has the positive scores higher than the negative scores. Fourth, from the Levene test of Homogeneity of Variances, it was found that the variance of groups population was the same or homogeneous. Fifth from the Anova (F test), it was found that the value of mean square from groups population was homogeneous and correlated to each other.

\section{REFERENCES}

Afni Tri. (1998). Some Problems in TEFL to the Third Year of Siudents from SLTPLB m. YPAC Palembarg. Unpublished Bachelor's 
Thesis.Indralaya: Faculty of teacher training and education, sriwijaya university.

Arikunto, Suharsimi. (1996). Proseda Research APrakiek approach. Jakarta: Rineka cipta.

Bootzin, R. R. (1986). Psychology Today: An Introduction 6 ed New York. NY Teacher Training and Education, Sriwijaya University. Rineka Cipta McGraw-Hill Inc.

Feldman, R.S. 1989. The Importance of Understanding Psychology. New York, NY. McGiraw-Hill.Inc.

Fraenkel, lack of $\mathrm{R}$ and Norman E. Wallen. (1991).Edhucational Reserch to Gardner, Howard 2003. Multiple Intelligence (Majemsuk Intelligence) Batam.

Ghozali, Imam. (2007). Application of Multivariate Analysis with SPSS Program.

Google.http: /www.okstate.edu/ag/agedem4h duvag / agedsmth / academic / aged5930a / 5980 / newpagci 6, html. "Questionnaire". Accessed on January 15, 2008.

Gregory, Robert J. (2004). Principles of Psychological Tests, and Himayana, Surtikayandi.2006. BenweenMfultiple Intelligence of the Process Correlation. New York: MCGrow Hill, Inc.

Popham, W James and Sirotnik, Kennet A. (1967). Educational Statistics: we and New York, NY: Interpreters of Happer Collins Publisher McGraw-Hill, Inc. Second Edition. Los Angeles: Harper and Row Publishers .

Rose, Collin. (1999). Kuasa Lebih Bubu Pintr Accelerated Learning. Bandung: Kaifa.

Rose,Collin, and Malcom J. Nicholl. (1997). Accclerated Learning for the 21th Century. London: Judy Piatkus.

Santrock,. J. W. (1991). Psychology of the Science of Mind and Beharvior. 3t ed Dallas, TX: Wm. C. Brown Publishers. 
Santrock,.John W and Lester M Sdorow. (2000). Selected Material from Psychology. Dubuque. IO: McGraw Hill Companies.

Seng, Tan Oon. (2003). Educational Psychology: A Practitioner Researcher Approach (AN Asian Edition). Shenton Way: Thomson.

Slavin, Robert E. (1997). Educational Psychology: Theory and Practice. (Fithedition ). Needham heights, NJ Viacom Company.

Surip, Rosdiana. (1994). The Relationship between the Intelligence and English edition). Needham Heights, NJ: A Achievement of the Third Year Students of SMA N 7 Palembang. Unpublished Undergraduate Thesis.

Popham, W James and Sirotnik, Kennet A. (1967). Educational Statistics. New York, NY: Interpreters of Happer Collins Publisher McGraw-Hill, Inc. Second Edition Los Angeles: Harper and Row Publishers.

Rose,Collin, and Malcom J. Nicholl. (1997). Accclerated Learning for the 21th Century. London: Judy Piatkus.

Rose, Collin. (1999). Kuasa Lebih Bubu Pintr Accelerated Learning. Bandung: Kaifa.

Santrock,. J. W. (1991). Psychology of the Science of Mind and Beharvior. 3t ed Dallas, TX: Wm. C. Brown Publishers.

Santrock,.John W and Lester M Sdorow. (2000). Selected Material from Psychology. Dubuque. IO: McGraw Hill Companies.

Seng, Tan Oon. (2003). Educational Psychology: A Practitioner Researcher Approach (AN Asian Edition). Shenton Way: Thomson.

Slavin, Robert E. (1997). Educational Psychology: Theory and Practice. (Fithedition ). Needham heights, NJ Viacom Company.

Surip,Rosdiana. (1994). The Relationship between the Intelligence and English edition). Needham Heights, NJ: A Achievement of the 
Kurnia Saputri: The Identification of Multile Intelligence in Relation to English Achievement|185

Third Year Students of SMA N 7 Palembang. Unpublished Undergraduate Thesis. 
186 | ENGLISH FRANCA, Vol. 2, No. 2, 2018 